\title{
RAZGLEDI
}

\section{VLOGA INTERPRETACIJE DEDIŠČINE V NARODNIH PARKIH}

\author{
AVTORICA \\ Anja Trobec \\ Znanstvenoraziskovalni center Slovenske akademije znanosti in umetnosti, Geografski inštitut Antona Melika, \\ Gosposka ulica 13, SI - 1000 Ljubljana, Slovenija \\ anja.trobec@zrc-sazu.si
}

DOI: $10.3986 / G V 87104$

UDK: 502/504:639.1.055.3(497.4+931)

COBISS: 1.02

\section{IZVLEČEK}

\section{Vloga interpretacije dediščine $v$ narodnih parkih}

V prispevku je predstavljena vloga interpretacije dediščine pri reševanju različnih izzivov, skaterimi se srečujejo narodni parki. Na kratko je predstavljen razvoj interpretacije dediščine, ki je neločljivo povezan s samim razvojem narodnih parkov. Analizirano in ovrednoteno je udejanjanje interpretacije dediščine $v$ Triglavskem narodnem parku $v$ Sloveniji in $v$ Fiordlandskem narodnem parku na Novi Zelandiji. Rezultati kažejo, da je interpretacija dediščine nepogrešljivo orodje pri upravljanju narodnih parkov, povečevanju njihove priljubljenosti, udejanjanju trajnostno zasnovanega turizma ter ozaveščanju javnosti o pomenu naravne in kulturne dediščine. Še vedno pa v narodnih parkih ostajajo številne neizkoriščene priložnosti za njeno izpopolnjenje.

\section{KLJUČNE BESEDE}

varstvo okolja, naravna dediščina, kulturna dediščina, zavarovana območja, Triglavski narodni park, Fiordlandski narodni park

\section{ABSTRACT}

\section{The role of heritage interpretation in national parks}

The article presents the role of heritage interpretation in solving the various challenges facing national parks. The evolution of heritage interpretation is presented, as it is inextricably connected to the development of the national parks themselves. The author analysed and evaluated the implementation of heritage interpretation in the Triglav National Park in Slovenia and the Fiordland National Park in New Zealand. The results show that heritage interpretation is an indispensable tool in managing national parks, increasing their popularity, implementing a sustainably devised tourism, and raising the public's awareness on the importance of parks natural and cultural heritage. However, many opportunities for its improvement in national parks remain unused.

\section{KEY WORDS}

environmental protection, natural heritage, cultural heritage, protected areas, Triglav National Park, National Park Fiordland

Uredništvo je prispevek prejelo 16. aprila 2015. 


\section{Uvod}

Nekatera naravna ali po človeku preoblikovana območja, naravni pojavi in oblike ter kulturni objekti imajo z estetskega, naravovarstvenega, umetnostnega, zgodovinskega, etnološkega ali antropološkega vidika tako velik pomen in vrednost, da jih uvrščamo med izjemne splošne vrednote. Te vrednote s skupnim izrazom imenujemo tudi naravna in kulturna dediščina (Convention ... 2015).

Ustanavljanje narodnih parkov izhaja iz prepričanja, da je območja s pestro naravno in kulturno dediščino smiselno varovati in jih ohraniti za prihodnje rodove (Smrekar s sodelavci 2014). Vendar vloga narodnih parkov z njihovo ustanovitvijo še zdaleč ni izpolnjena. Za uspešno varstvo te dediščine je namreč potrebno stalno udejstvovanje celotne družbe (Bizjak 2004). Na načelni ravni sicer velja, da je današnja družba naklonjena različnim oblikam varstva naravne in kulturne dediščine, vendar v praksi pogosto ni tako (Bizjak 2011). Posledično se upravljavci narodnih parkov pri svojem delu srečujejo $\mathrm{z}$ izzivi, kot so nenatančna opredelitev pomena in vloge narodnih parkov, pojav različnih, pogosto izključujočih želja in s tem napetosti med deležniki v parkih (Lampič in Mrak 2008), pomanjkanje politične volje za ustanavljanje in učinkovito upravljanje obstoječih parkov (Ogorelec 2011) ter neupoštevanje varstvenih režimov v parkih (Lampič in Mrak 2008; Plut 2008). Te in številne druge izzive skušajo upravljavci narodnih parkov reševati na različne načine. Mednje se uvršča tudi interpretacija dediščine, ki razkriva pomen tistega, kar interpretiramo (Ham 1992). Njen razvoj je neločljivo povezan z razvojem narodnih parkov (Tilden 1957; Harper 1991; Ogorelec 2004). Upravljavci parkov interpretacijo dediščine dandanes uporabljajo kot storitev za bogatenje izkušenj in povečanje zadovoljstva obiskovalcev. Interpretacija dediščine poleg tega služi kot orodje za upravljanje s parki (vključno z upravljanjem obiska) in kot sredstvo za vzpostavljanje, grajenje in vzdrževanje odnosov s širšo javnostjo (Harper 1991). S tem namenom se je poslužujejo tudi v Triglavskem narodnem parku (v nadaljevanju TNP) v Sloveniji in Fiordlandskem narodnem parku (v nadaljevanju FNP) na Novi Zelandiji. Sredstva interpretacije dediščine v narodnih parkih pa bi bilo za potrebe učinkovitejšega varstva naravne in kulturne dediščine smiselno še izpopolniti (Veverka 2011).

Namen članka je presoja vloge interpretacije dediščine pri reševanju ključnih izzivov narodnih parkov, kot so njihovo učinkovito upravljanje, povečevanje priljubljenosti, udejanjanje trajnostno zasnovanega turizma ter ozaveščanje javnosti o pomenu naravne in kulturne dediščine, kot tudi analiza udejanjanja interpretacije dediščine v TNP-ju in FNP-ju.

\section{Triglavski narodni park in Fiordlandski narodni park}

Primerjava udejanjanja interpretacije dediščine v TNP-ju in FNP-ju je primerna, ker med obema obstajajo številne podobnosti (preglednica 1). S parkoma od njune ustanovitve v drugi polovici 20. stoletja dalje upravljata javna zavoda. Parka se razprostirata na približno $4 \%$ površine državnega ozemlja in predstavljata največji zavarovani območji v državi. Zaznamuje ju vlažno podnebje in razgibana ledeniško preoblikovana gorska pokrajina, ki je prepredena s številnimi vodotoki in stoječimi vodami, pretežno poraščena $\mathrm{z}$ bukovimi gozdovi in redko ali celo neposeljena. Za oba parka so značilna raznolika in obsežna naravna območja s pestro naravno dediščino, tradicionalna prisotnost človeka in izkoriščanje naravnih virov, kot so les, voda in rude. Med prevladujoče in najhitreje rastoče gospodarske panoge se uvršča turizem, ki hkrati povzroča tudi največje pritiske na okolje (Cvahte 2013).

Na podlagi skupnih značilnosti sklepamo, da so vsebina in uporabljena sredstva interpretacije dediščine v obeh parkih sorodna in primerljiva.

$S$ primerjavo smo želeli tudi preveriti ali je interpretacija dediščine, zaradi daljše tradicije $v$ angleško govorečih državah, v FNP-ju bolj razvita in uveljavljena kot v TNP-ju. 
Preglednica 1: Naravno- in družbenogeografske značilnosti Triglavskega narodnega parka in Fiordlandskega narodnega parka.

\begin{tabular}{lll}
\hline & Triglavski narodni park & Fiordlandski narodni park \\
\hline ustanovitev & 1961 (raž̌irjen) & 1952 \\
upravljavec & Javni zavod TNP & Javni zavod za ohranjanje \\
geografska lega & Julijske Alpe & Južne novozelandske Alpe \\
površina & 83.982 ha & 1.300 .000 ha \\
pokrovnost & visokogorski svet, gozd, voda & visokogorski svet, gozd, voda \\
lastništvo zemljišč & privatno in javno & javno \\
poselitev & redka in razpršena & ni stalnih prebivalcev \\
gospodarske dejavnosti & turizem, kmetijstvo & turizem, ribištvo, proizvodnja \\
& & hidroenergije \\
dediščina & naravna in kulturna & predvsem naravna \\
ključni okoljski problemi in izzivi & obremenjevanje okolja zaradi & $\begin{array}{l}\text { obremenjevanje okolja zaradi } \\
\text { turizma }\end{array}$ \\
\hline
\end{tabular}

\section{Metode}

Večino podatkov o značilnostih interpretacije dediščine v TNP-ju in FNP-ju smo pridobili s pregledom tiskovin in spletnih strani ter s terenskim delom. Opravili smo razgovore z zaposlenimi $\mathrm{v}$ središčih za obiskovalce v FNP-ju ter intervjuvali takratnega direktorja TNP-ja, mag. Martina Šolarja. Večino podatkov smo zbrali v letih 2011, 2012 in 2013.

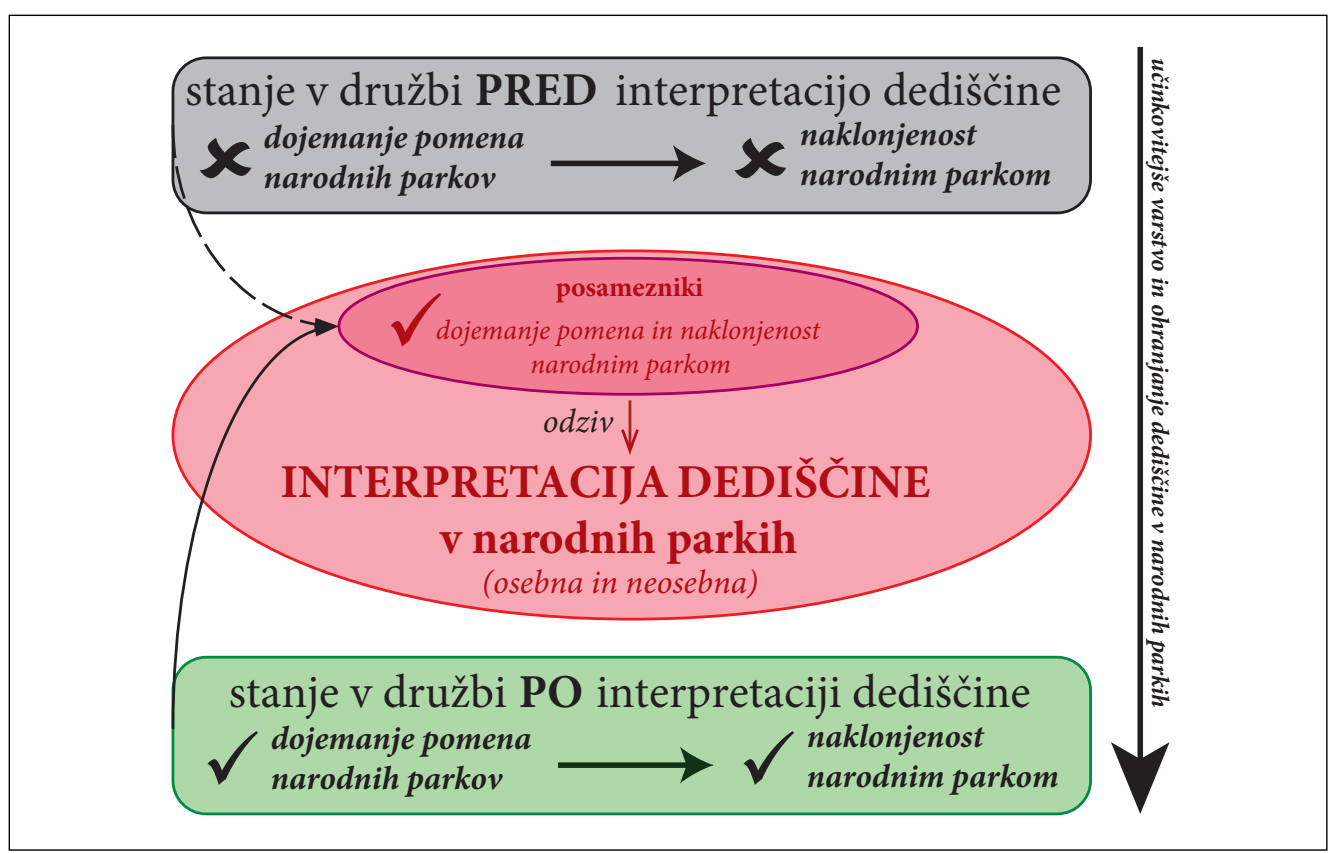

Slika 1: Prilagojen socialnoekološki model (Špes 1994). 
Na podlagi pridobljenih podatkov smo podali nekaj ključnih predlogov za nadaljnji razvoj interpretacije dediščine v narodnih parkih.

V raziskavi smo delno sledili socialnoekološkemu pristopu (slika 1) (Špes 1994).

\section{Interpretacija dediščine}

Utemeljitelj sodobne interpretacije dediščine Freeman Tilden iz Združenih držav Amerike je v svoji knjigi Interpreting Our Heritage (1957) zapisal, da je interpretacija dediščine vzgojno-izobraževalna dejavnost $\mathrm{s}$ ciljem razkriti pomen ter odnose v naravi in družbi $\mathrm{z}$ uporabo izvirnih predmetov, z ustvarjanjem izkušenj iz prve roke ter s pomočjo ponazarjajočih sredstev in ne zgolj s podajanjem nepristranskih dejstev. Ham (1992) navaja, da interpretacija dediščine ustvarja pomen in razumevanje tistega, kar interpretiramo. Ogorelčeva (2004) pa dodaja, da interpretacija dediščine besedila strokovnjakov prevaja v jezik »običajnih « ljudi. $\mathrm{Z}$ njo ne le informiramo, temveč tudi razkrivamo in ozaveščamo. Erhartič s sodelavci (2012) meni, da s pomočjo interpretacije domačinom in obiskovalcem pomagamo spoznavati in ceniti tisto, kar je stroka označila kot posebej vredno: naravo in njene dele, kulturno pokrajino, zgodovinske dogodke in podobno. Interpretacija pomaga razumeti pokrajino, spodbuja zanimanje obiskovalca za naravne vrednote in kulturno dediščino ter skrbi za njuno ohranjanje (Tilden 1957).

V širšem pomenu besede je interpretacija dediščine $v$ družbi prisotna že dolgo, v sodobnem pomenu pa gre za novejši pojav (Smrekar s sodelavci 2014), ki je tesno prepleten z razvojem narodnih parkov in uveljavljanjem turistične dejavnosti na njihovih območjih. Zametki interpretacije dediščine segajo $\mathrm{v}$ čas ustanavljanja in razvoja prvih narodnih parkov v Združenih državah Amerike. Sprva so se razvila interpretacijska vodenja, šele kasneje je sledil razvoj ostalih osebnih in neosebnih sredstev interpretacije (Harper 1991).

Izraz »interpretacija « je v povezavi s sporazumevanjem, razumevanjem in razkrivanjem pomena dediščine prvi uporabil John Muir leta 1871. O interpretaciji dediščine kot stroki pa je na začetku 20. stoletja prvi pisal, in dediščino v parkih Združenih držav Amerike poklicno interpretiral, ameriški naravoslovec Enos Mills (Thorsten 2003).

Interpretacijo dediščine zavzeto razvijajo v narodnih parkih po vsem svetu. Najbolj je uveljavljena v narodnih parkih Združenih držav Amerike (Lackey 2008), Kanade, Avstralije, Nove Zelandije in Združenega kraljestva (Erhartič s sodelavci 2012; Some ... 2015).

Po besedah svetovno priznanih interpretatorjev, kot sta Američana Sam H. Ham (1992) in John Veverka (2011), je najmočnejše orodje interpretacije dediščine njena tema. Gradimo jo okrog glavne točke, ki jo želimo predstaviti. S pomočjo teme torej predstavimo bistvo dediščine, pri čemer si pomagamo z različnimi neosebnimi sredstvi interpretacije, kamor med drugim uvrščamo table in panoje, poti, opremljene s tablami, središča za obiskovalce, tiskovine, razstave, spletne strani in interaktivne predstavitve ter osebnimi sredstvi interpretacije, kot so vodenja, pripovedovanja, prikazovanja, uprizarjanja, poučevanja, delavnice in tečaji (Keršič-Svetel 2010).

\section{Vloga interpretacije dediščine v narodnih parkih}

Z interpretacijo dediščine je mogoče doseči izobraževalne, vedenjske in čustvene cilje (Ogorelec 2004). Od začetka 21. stoletja se v narodnih parkih vse bolj uveljavlja in pogosteje uresničuje zamisel, da lahko interpretacija dediščine, preko ustvarjanja pomena narodnih parkov in dediščine v njih, pripomore $\mathrm{k}$ odpravi številnih problemov in izzivov, s katerimi se upravljavci narodnih parkov dnevno srečujejo pri svojem delu. Utrjuje se tudi prepričanje, da lahko z njeno pomočjo dosežemo ključne upravljavske cilje, med katerimi je na prvem mestu varstvo dediščine (Veverka 2015). 
Prvotna in dolgo časa edina vloga interpretacije dediščine v narodnih parkih je bila poučevanje in zabavanje obiskovalcev oziroma bogatenje njihovih izkušenj z dediščino. Namen interpretatorjev je bil na zanimiv način razkriti pomen dediščine in vlogo narodnih parkov, da bi jih javnost podprla in sprejela kot vrednoto (Tilden 1957). Do pred kratkim se torej nismo zavedali prave vrednosti interpretacije dediščine in vseh možnosti, ki jih ponuja. $V$ zadnjem času pa te možnosti pospešeno spoznavamo, s čimer se vsestranska vloga interpretacije dediščine vztrajno krepi. Uporabljati smo jo začeli tudi v procesu ustanavljanja in upravljanja narodnih parkov, saj smo spoznali, da brez interpretacije dediščine narodni parki izgubljajo priložnost za predstavitev svoje »zgodbe«, poslanstva in svojega vsestranskega pomena za dobrobit celotne družbe (Ryan in Dewar 1995; Merriman in Brochu 2004; Hlad 2004).

Izvajanje interpretacije dediščine in njeno vključevanje v razna področja upravljanja spadata med pomembne naloge upravljavcev narodnih parkov, katerih temeljni namen je zagotoviti učinkovito varstvo dediščine. S pomočjo interpretacije obiskovalci, lokalni prebivalci in ostala širša javnost dediščino v narodnih parkih lažje vzljubijo, doumejo in dojamejo kot vrednoto. Začno se zanimati zanjo, se z njo poistoveti, so ponosni nanjo, jo razumejo in spoštujejo, podprejo upravljanje z njo ter razvijejo občutek odgovornosti in potrebo po vključevanju v njeno varstvo. Ob vsem tem se poveča tudi priljubljenost parkov, njihov obisk in ne nazadnje tudi njihovi prihodki (Wearing s sodelavci 2008; Erhartič s sodelavci 2012).

Pomembna naloga interpretacije dediščine je povezovanje upravljavcev narodnih parkov $\mathrm{z}$ ostalimi ponudniki storitev za obiskovalce, kot so lokalni prebivalci, okoliški kmetovalci, gostinci, hotelirji in krajevne turistične organizacije. Zaradi tovrstnega povezovanja obiskovalci lažje dostopajo do raznovrstnih informacij o zavarovanem območju, se pogosteje odločajo za njegov obisk, med obiskovalci in ponudniki storitev pa se krepi zavedanje pomena tega območja in njegove dediščine, razvoj območja poteka skladneje $\mathrm{z}$ načeli trajnosti, varstvo dediščine pa je posledično učinkovitejše (Baldauf in sodelavci 2011).

Upravljavci narodnih parkov s sredstvi interpretacije dediščine obiskovalce usmerjajo in jih poskušajo obdržati na označenih poteh (Winter 2006). Usmerjajo jih na bolj obiskana privlačna območja "vroče točke (Pretner in Šolar 2006), na z ekosistemskega vidika manj občutljiva območja ter na območja, ki so zaradi pretiranega obiska že degradirana do te mere, da jih upravljavci namenoma "žrtvujejo « in na ta način ohranjajo ostala bolj ranljiva območja (Moscardo 1996; Baldauf s sodelavci 2011). Prek sredstev interpretacije dediščine obiskovalce učimo tudi pravil vedenja v parku, s čimer preprečujemo neželene in za dediščino škodljive vedenjske vzorce, ter gradimo trajen in boljši odnos med upravljavci in ostalimi deležniki (Harper 1991; Veverka 2011).

Za potrebe obveščanja in ozaveščanja javnosti o pomenu upravljanja narodnih parkov, imajo upravljavci v interpretacijo dediščine možnost vključiti tudi informacije o svoji vlogi v parku, pooblastilih in obsegu svojega dela (Vadala, Bixler in Hammitt 2006).

Interpretacija dediščine pa je poleg vsega naštetega tudi temeljna sestavina trajnostnega turizma. Wallace in Pierce (1996) takšno obliko turizma opredeljujeta kot dejavnost obiskovanja naravnega okolja z namenom globljega uživanja in doživljanja pokrajine, izobraževanja in sodelovanja pri prostovoljnem delu. Zanimanje obiskovalcev je usmerjeno predvsem k spoznavanju dediščine narodnih parkov ter razlogov za njeno varstvo (Keršič-Svetel 2002). Takšne oblike turizma torej brez kakovostne interpretacije dediščine ni mogoče učinkovito razviti (Ham 2003; Veverka 2011).

\section{Udejanjanje interpretacije dediščine v Triglavskem narodnem parku in Fiordlandskem narodnem parku}

Interpretacija dediščine ima v FNP-ju daljšo tradicijo kot v TNP-ju, saj se je v FNP-ju začela razvijati ob njegovi ustanovitvi, v TNP-ju pa šele po sprejetju Zakona o Triglavskem narodnem parku leta 1981.

V FNP-ju poteka pod okriljem Javnega zavoda za ohranjanje (Department of Conservation) - krovne organizacije, ki upravlja z večino zavarovanih območij na Novi Zelandiji (Medmrežje 1), udejanjanje 
interpretacije v TNP-ju pa je v domeni Javnega zavoda Triglavski narodni park, ki upravlja zgolj s TNP-jem. Posledično prihaja pri interpretaciji dediščine med različnimi zavarovanimi območji v Sloveniji, ki jih upravljajo različne ustanove, do večjih vsebinskih in metodoloških razlik (Šolar 2012), medtem ko je v zavarovanih območjih Nove Zelandije interpretacija dediščine enotnejša (Department ... 2012).

Noben izmed omenjenih upravljavcev nima izdelanega celovitega načrta interpretacije dediščine, ki je temelj za njen uspešen razvoj in učinkovito udejanjanje.

Uradni moto Javnega zavoda TNP je »Spoznavati, doživljati, razumeti TNP«, kar nakazuje na to, da je upravljanje parka prežeto $\mathrm{z}$ interpretacijo dediščine oziroma da upravljavec pri svojem delu upošteva njena temeljna načela. Kljub temu pa se samega pojma »interpretacija« še vedno ne poslužuje.

Izvajanje osebnih oblik interpretacije dediščine je Javni zavod za ohranjanje skoraj v celoti prenesel na koncesionarje, Javni zavod TNP pa interpretacijo dediščine pretežno izvaja sam ali v sodelovanju $\mathrm{z}$ drugimi deležniki v parku (lokalni prebivalci, osnovne šole, krajevne turistične organizacije), z upravljavci zavarovanih območij v tujini in zunanjimi strokovnimi sodelavci. Vendar pa predvsem lokalni prebivalci niso vedno pripravljeni na sodelovanje, zato upravljavcu za učinkovito udejanjanje interpretacije dediščine občasno primanjkuje ustreznih izvajalcev (Šolar 2012).

Javni zavod za ohranjanje in Javni zavod TNP imata deloma različne razloge za udejanjanje interpretacije dediščine v parkih. Namen obeh je z interpretacijo dediščine lokalne prebivalce in obiskovalce ozaveščati o pomenu dediščine $\mathrm{v}$ parku ter s tem doseči njihovo spoštovanje dediščine in odgovorno ravnanje z njo. Pomemben skupni cilj je tudi usmerjanje obiskovalcev na označene poti in do urejenih znamenitosti ter s tem preprečevanje degradacije okolja. Vendarle pa Javni zavod za ohranjanje interpretacijo dediščine prednostno uporablja kot sredstvo za povečevanje priljubljenosti in $s$ tem obiska FNP-ja, kar za Javni zavod TNP ne velja. Obisk TNP-ja naj bi namreč na nekaterih območjih že sedaj presegal nosilne zmogljivosti (Šolar 2012).

V obeh parkih se je interpretacija kulturne dediščine uveljavila za interpretacijo naravne dediščine. Sprva so se v obeh parkih razvijala predvsem neosebna sredstva interpretacije dediščine (sliki 2 in 3), kot so poti, opremljene s tablami, središča za obiskovalce, tiskovine in razstave. V zadnjem času je v obeh parkih vedno več poudarka na interaktivnih predstavitvah ter udejanjanju osebnih oblik interpretacije, kot so vodenja po parku, delavnice, pripovedovanja, doživljajski programi, tečaji in podobno. V TNP-ju vodenja izvajajo predvsem nadzorniki parka, v FNP-ju pa so to prakso opustili in vodenje povečini prepustili koncesionarjem. Tako Javni zavod za ohranjanje kot Javni zavod TNP občasno organizirata izobraževanja za interpretacijske vodnike po parku.

Vsa sredstva interpretacije dediščine upravljavca spretno oglašujeta na spletnih straneh parka ter $\mathrm{v}$ številnih tiskovinah, kot so zgibanke ter redne in priložnostne publikacije.

V primerjavi s TNP-jem v FNP-ju pri interpretiranju uporabljajo nekoliko več različnih sredstev neosebne interpretacije. Nekatere poti so tako v FNP-ju namesto s tablami opremljene z oštevilčenimi količki in interpretacijskimi letaki, ki opisujejo dediščino ob teh količkih (slika 4). Številne plakate, table in druge oblike sredstev interpretacije zasledimo tudi v planinskih postojankah in zasebnih nastanitvenih objektih.

Po drugi strani pa je Javni Zavod TNP uvedel premično informacijsko točko (prevozno sredstvo, ki potuje po parku in okolici ter na poučen in zanimiv način predstavlja park ter njegovo dediščino).

Interpretacija vseh vrst dediščine se torej izvaja $\mathrm{z}$ raznolikimi in v večini primerov dobro zastopanimi ter razvitimi osebnimi in neosebnimi sredstvi. Nekatera sredstva se zaradi manjšega zanimanja obiskovalcev, pomanjkanja finančnih sredstev in/ali izurjenih interpretatorjev v obeh parkih opuščajo. Primer sredstva v opuščanju je Pokljuška pot v TNP-ju, ki ni nikoli zaživela v polni meri. Odkar so jo uredili, se na tem območju pojavljajo vetrolomi, odvijajo se sečnje in spravila lesa, ljudje pa se po vlakah vozijo z masivnimi prevoznimi sredstvi in jih na ta način uničujejo (Šolar 2012). V FNP-ju so

Slika 2: Sredstva interpretacije dediščine v Triglavskem narodnem parku.

Slika 3: Sredstva interpretacije dediščine v Fiordlandskem narodnem parku. $>$ str. 70 


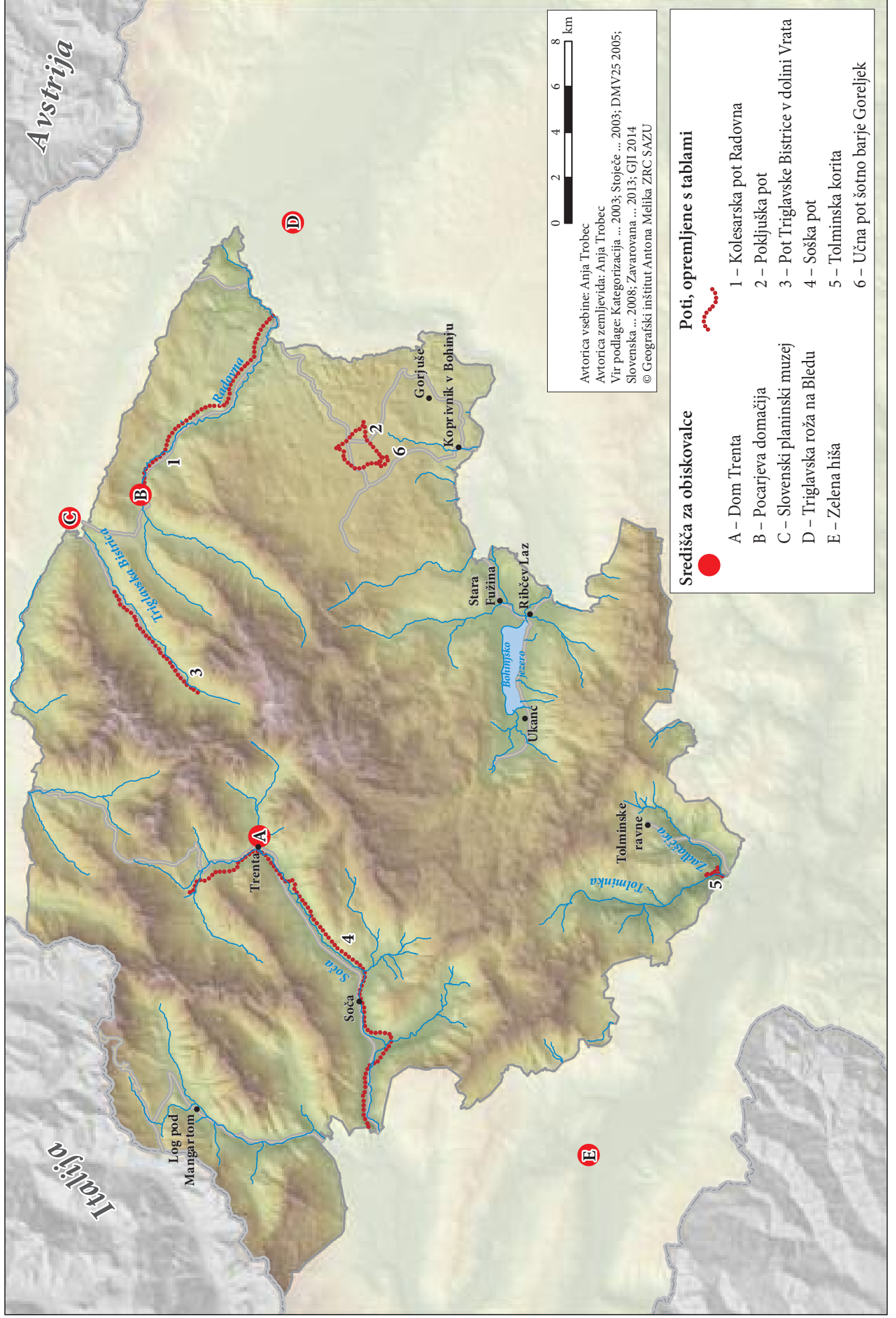




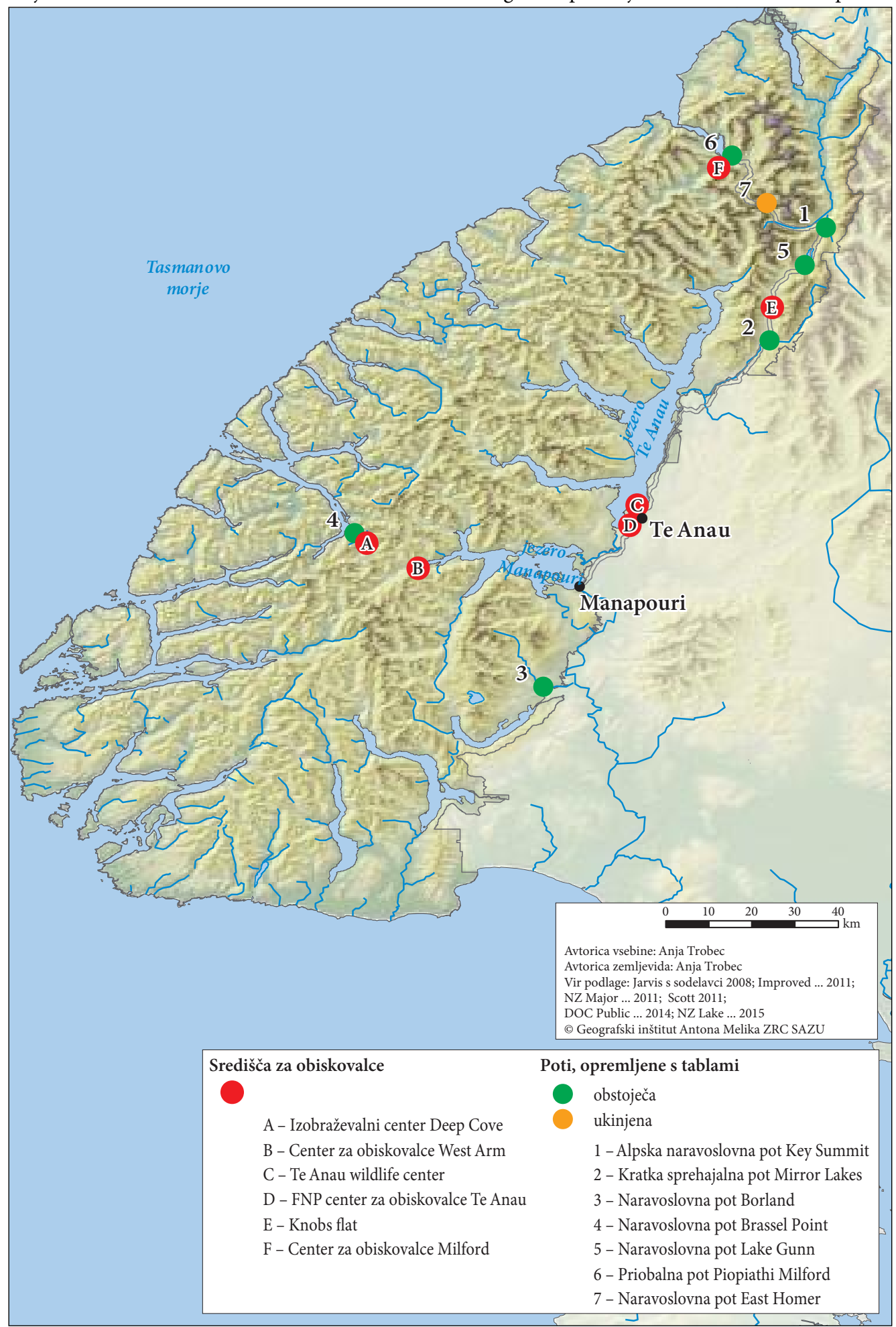




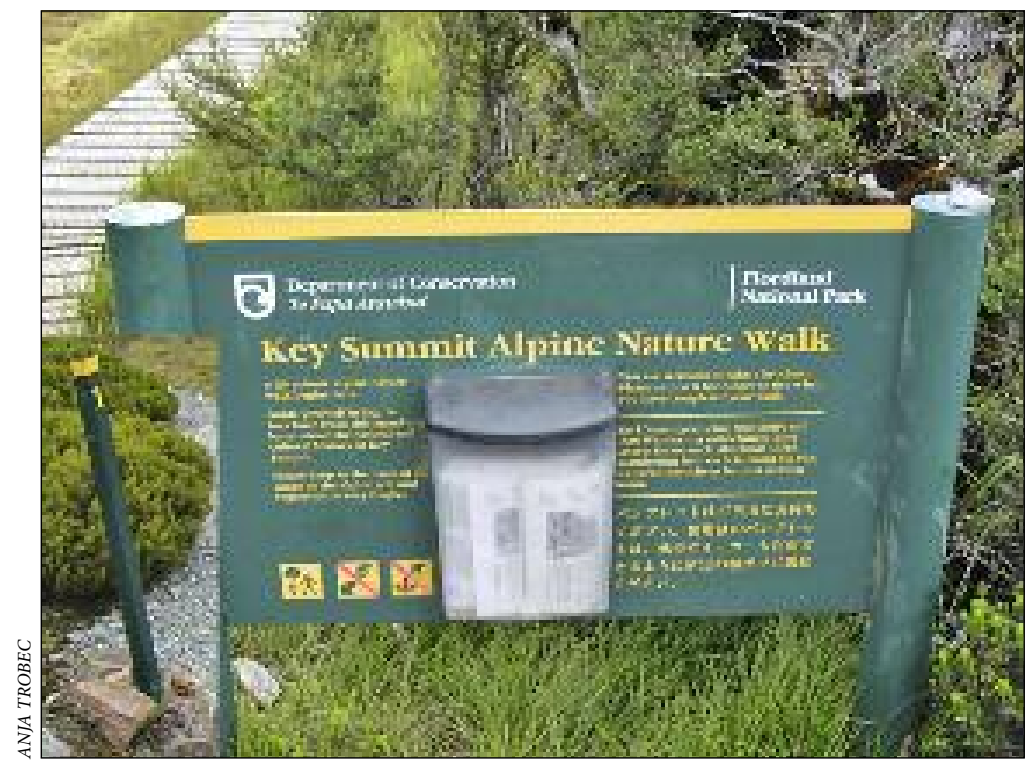

Slika 4: Pot v Fiordlandskem narodnem parku, opremljena z letaki in oštevilčenimi količki.

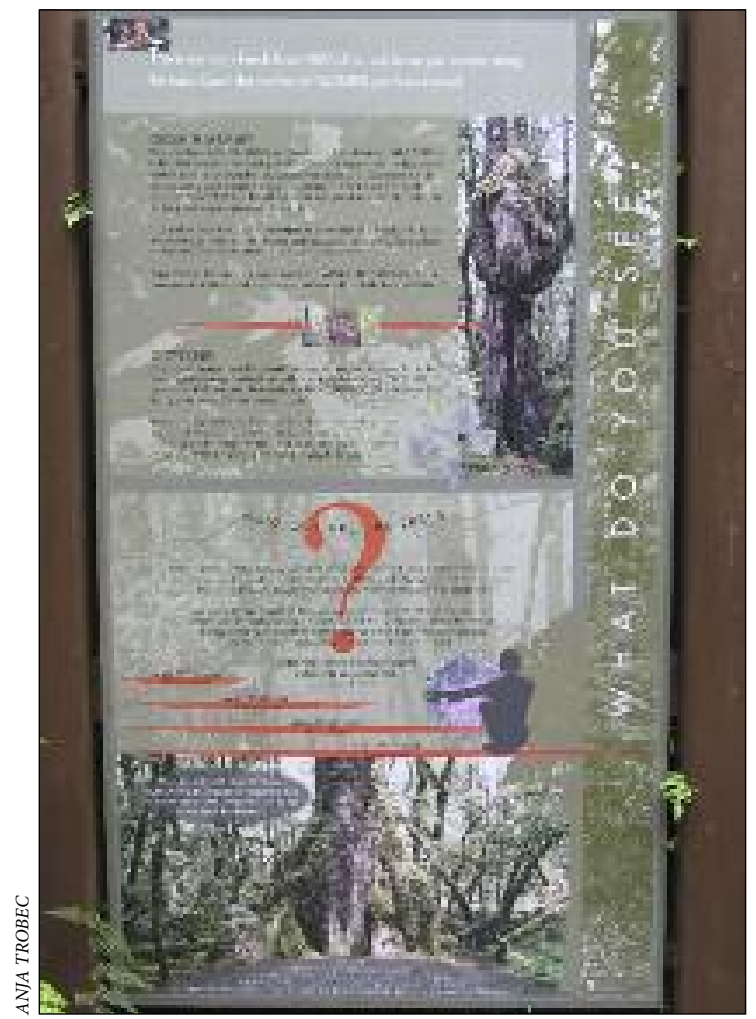

Slika 5: Primer interpretacijske table ob Naravoslovni poti Lake Gunn. 
zaradi slabe obiskanosti oziroma nepriljubljenosti opustili Naravoslovno pot East Homer (slika 2) (FNP ... 2012; East ... 2015).

Javni zavod za ohranjanje ima v FNP-ju namen povečati število neosebnih sredstev interpretacije dediščine, na primer poti, opremljenih s tablami. V po površini skoraj 16-krat manjšem TNP-ju, ki je že leta 2009 razpolagal s prek 1700 objekti parkovne infrastrukture (Šolar 2009), pa naj se število neosebnih sredstev interpretacije v prihodnje ne bi bistveno povečalo (Šolar 2012).

Preglednica 2: Značilnosti parkovnih poti, opremljenih s tablami.

\begin{tabular}{|c|c|c|c|}
\hline značilnosti poti & TNP & FNP & priporočila Veverka (2011) \\
\hline število poti & 6 & 6 & \\
\hline $\begin{array}{l}\text { gostota (število poti/ } \\
100 \mathrm{~km}^{2} \text { parka) }\end{array}$ & 0,71 & 0,05 & \\
\hline $\begin{array}{l}\text { število krožnih poti } \\
\text { od vseh poti }\end{array}$ & 3 & 4 & krožna oblika poti \\
\hline dostopnost & lahka & $\begin{array}{c}\text { povečini lahka } \\
\text { (Naravoslovna pot Brassel } \\
\text { Point dostopna le z ladjo) }\end{array}$ & $\begin{array}{c}\text { lahka dostopnost } \\
\text { z začetkom na bolj } \\
\text { obljudenih območjih }\end{array}$ \\
\hline varnost & večinoma zagotovljena & zagotovljena & $\begin{array}{c}\text { obvezno zagotoviti } \\
\text { varnost obiskovalcev } \\
\text { na poti }\end{array}$ \\
\hline vzdrževanje & večinoma ustrezno & ustrezno & redno vzdrževanje \\
\hline povprečna dolžina $(\mathrm{km})$ & 9,2 & 0,9 & $0,8-1,2$ \\
\hline število poti ustrezne dolžine & 2 & 0 & \\
\hline $\begin{array}{l}\text { povprečno število točk } \\
\text { s tablami }\end{array}$ & 10 & 12 & $7-10$ \\
\hline $\begin{array}{l}\text { število poti z ustreznim } \\
\text { številom točk s tablami }\end{array}$ & 3 & 1 & \\
\hline snovi za izdelavo tabel & pretežno les in plastika & $\begin{array}{l}\text { pretežno kovina } \\
\text { in plastika }\end{array}$ & $\begin{array}{l}\text { uporaba krajevnih } \\
\text { naravnih snovi }\end{array}$ \\
\hline stapljanje tabel z okolico & $\begin{array}{l}\text { da (prevladujejo } \\
\text { rjave table) }\end{array}$ & $\begin{array}{c}\text { delno (prevladujejo } \\
\text { zeleno-rumene table, } \\
\text { nekaj je raznobarvnih) }\end{array}$ & $\begin{array}{l}\text { stapljanje z okolico } \\
\text { in barvna usklajenost } \\
\text { tabel z okolico }\end{array}$ \\
\hline prisotnost vodilne teme & ponekod & ponekod & obvezna \\
\hline vsebina na tablah & pretežno informacijska & pretežno interpretacijska & interpretacijska \\
\hline besedilo na tablah & preveč strokovno & povečini preprosto & preprosto (»jezik laikov«) \\
\hline $\begin{array}{l}\text { osnovne informacije } \\
\text { na tabli ob začetku poti }\end{array}$ & zadostne (slika 6) & pomanjkljive & $\begin{array}{c}\text { zemljevid, osnovne } \\
\text { informacije o poteku poti, } \\
\text { čas hoje, varnostna } \\
\text { opozorila }\end{array}$ \\
\hline $\begin{array}{l}\text { spremljajoče } \\
\text { zgibanke/letaki }\end{array}$ & povečini zanimive & $\begin{array}{l}\text { povečini zanimive } \\
\text { zgibanke in letaki }\end{array}$ & zanimive in izzivalne \\
\hline $\begin{array}{l}\text { prisotnost dodatne } \\
\text { infrastrukture }\end{array}$ & da & da & $\begin{array}{l}\text { klopi in ostali pripomočki } \\
\text { za oddih ob poti }\end{array}$ \\
\hline
\end{tabular}


Upravljavca obeh območij sta interpretacijo dediščino prepoznala tudi kot pomembno orodje upravljanja parka, predvsem upravljanja z obiskom. S pomočjo različnih sredstev interpretacije dediščine, kot so table in tiskovine, obiskovalce usmerjata po parku, jih poskušata zadržati na urejenih poteh ter jih seznanjata $s$ pravili ustreznega vedenja $\mathrm{v}$ različnih delih parka. $\mathrm{S}$ pomočjo interpretacije jim dediščino predstavljata na način, da se začnejo zavedati njenega pomena in ji s svojim ravnanjem v parku ne škodujejo.

S primerjavo predvsem neosebnih sredstev interpretacije dediščine med parkoma smo prišli do sklepa, da sredstva v FNP-ju povečini interpretirajo dediščino, medtem ko v TNP-ju pretežno zgolj podajajo informacije o dediščini. Obiskovalcem sredstva interpretacije v FNP-ju namreč razkrivajo zgodbo ter $\mathrm{v}$ večji meri vzpostavljajo odnos med obiskovalci in interpretirano dediščino. Obiskovalcem je na tablah in prek drugih sredstev interpretacije zastavljenih tudi veliko vprašanj, poleg tega pa so spodbujeni $\mathrm{k}$ lastnemu raziskovanju območja in dediščine (slika 5).

Kot je razvidno iz preglednice 2 , ki predstavlja značilnosti najbolj uveljavljenega sredstva interpretacije dediščine v obeh narodnih parkih - poti, opremljenih s tablami, sredstva interpretacije dediščine le delno sledijo načelom in priporočilom za uspešno interpretacijo (Veverka 2011).

Iz primerjave udejanjanja interpretacije dediščine $\mathrm{v}$ obeh parkih je razvidno, da kljub krajši tradiciji interpretacija dediščine v TNP-ju ni nič manj kakovostna kot v FNP-ju. Razvoj, vsebina, sredstva, način in razlogi za izvajanja interpretacije dediščine se med parkoma sicer nekoliko razlikujejo, v obeh pa je, kljub že sedaj razmeroma kakovostnemu izvajanju interpretacije dediščine, le-to mogoče še izboljšati.

\section{Razprava}

Zavarovanje območij, med drugim v obliki narodnih parkov, in vzpostavljanje posebnih varstvenih režimov znotraj njih, je najpogostejši ukrep, s katerim želimo zagotoviti varstvo dediščine na nekem območju (Hribar, Šmid - Hribar, Erhartič 2011). Ker je aktivna skrb za celotno pokrajino tako rekoč

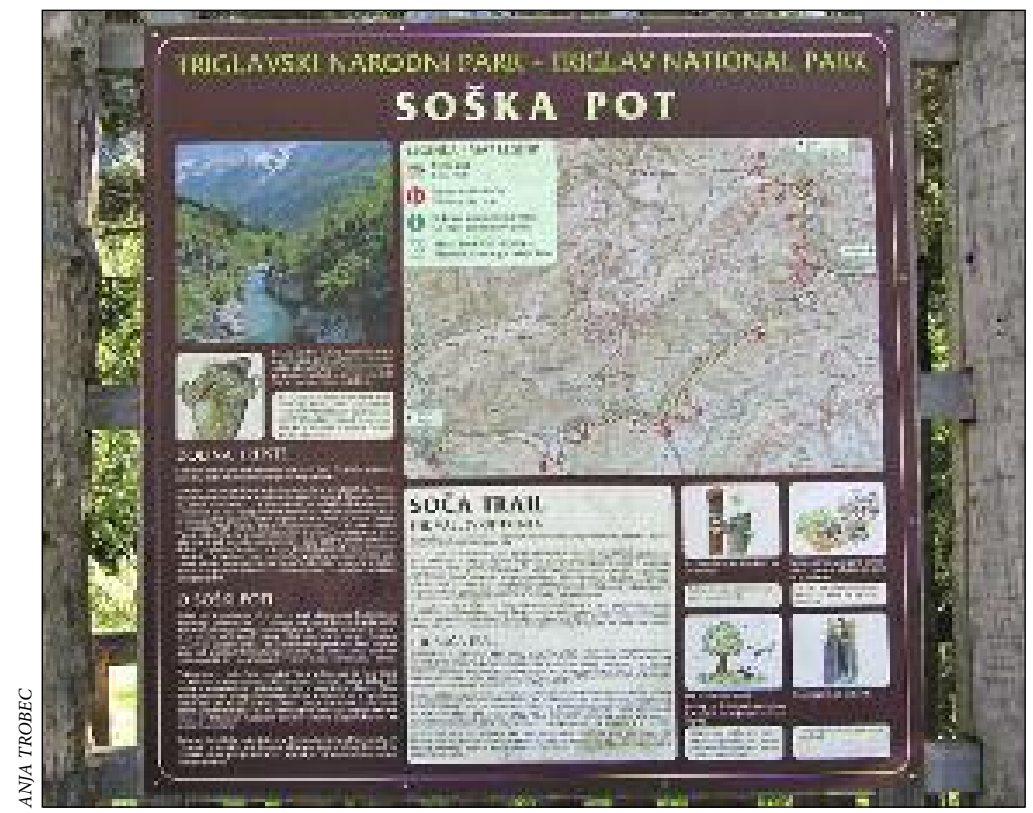

Slika 6: Primer table ob začetku Soške poti. 
neizvedliiva, se zavzeto varuje predvsem tiste naravne in kulturne prvine v pokrajini, ki jih družba spozna za vrednoto (Grošelj 2008).

Kljub izjemnemu pomenu in vlogi narodnih parkov pri ohranjanju naravne in kulturne dediščine prevelik del današnje družbe parkov še vedno ne prepozna kot vrednoto, temveč kot omejitev, kar vodi $\mathrm{k}$ številnim nerešenim problemom. Najbolj pereča sta premajhna naklonjenost parkom s strani držav, širše javnosti in lokalnih prebivalcev ter posledično slabše udeleževanje pri varstvu naravne in kulturne dediščine na njihovem območju. Lokalni prebivalci parkom pogosto niso naklonjeni zaradi strožjih omejitev, ki veljajo znotraj parkov, saj se zaradi njih pri svojem delovanju nemalokrat počutijo prikrajšano in zapostavljeno (Lampič in Mrak 2008). Države pa po ustanovitvi narodnih parkov do njih prepogosto postanejo brezbrižne, medtem ko področne politike pri povezovanju in doseganju razvojnih ciljev ter ciljev varstva naravne in kulturne dediščine na območju parkov pogosto ne sodelujejo (Sovinc 2011). Posledično prevladuje mnenje, da varstvo in razvoj nista združljiva pojma ter da (za)varovanje predstavlja razvojno oviro (Lampič in Mrak 2008). Upravljavcem narodnih parkov zato neprestano primanjkuje denarnih sredstev (Lampič in Mrak 2007), človeških virov (Groznik - Zeiler 2011) in kakovostnih upravljavskih načrtov (Sovinc, Fišer - Pečnikar in Gosar 2011).

Obiskovalci zaradi neupoštevanja varstvenih režimov, slabega poznavanja razlogov za ustanovitev narodnih parkov ter nezavedanja ali slabega dojemanja njihovega pomena, naravne in kulturne dediščine v parkih pogosto ne cenijo in ji s svojim ravnanjem (ne)namerno škodujejo (Kus - Veenvielt in Sovinc 2009; Department ... 2014).

Poleg tega so estetska vrednost pokrajine, območja $\mathrm{z}$ lastnostmi divjine, kakovostno okolje, trajnostni prostorski razvoj in izjemna kulturna dediščina v narodnih parkih tako s strani lokalnih prebivalcev in obiskovalcev kot tudi upravljavcev preredko prepoznani kot vrednota, zaradi česar je njihovo varstvo pogosto neustrezno oziroma se ga zapostavlja (Lampič in Mrak 2008).

Kljub vsemu pa del družbe predstavljajo tudi okoljsko ozaveščeni posamezniki, ki narodne parke dojemajo kot vrednoto potrebno varstva. Svoje dojemanje in željo po aktivnem udeleževanju pri varstvu dediščine parkov želijo prenesti na preostali del družbe. Pri tem si vse pogosteje pomagajo z interpretacijo dediščine oziroma z njenimi sredstvi. Družba, ki je deležna kakovostne interpretacije dediščine, je okoljsko bolj ozaveščena in se v večji meri zaveda pomena ter potrebe po varstvu narodnih parkov. Interpretacija dediščine tako med drugim vpliva na večjo sprejetost parkov v družbi. Varstvo dediščine je v družbi, ki je parkom naklonjena, manj zahtevno in učinkovitejše.

Upravljavci narodnih parkov morajo zato $\mathrm{v}$ večji meri težiti $\mathrm{k}$ uvajanju in uveljavljanju interpretacije dediščine v narodnih parkih ter k oblikovanju kakovostnih načrtov interpretacije dediščine. Od teh načrtov je namreč odvisno, kako uspešen bo razvoj interpretacije dediščine v narodnih parkih, kako učinkovito bo njeno izvajanje in v kolikšni meri bomo z njeno pomočjo dosegli zastavljene upravljavske cilje (Harper 1991; Benton 2009).

Ker narodni parki zadevajo tako upravljavce kot tudi lokalne prebivalce, obiskovalce in širšo javnost, bi se morali vsi ti deležniki aktivneje vključiti v izvajanje interpretacije dediščine v parkih. S tem bi dosegli boljše poznavanje naravne in kulturne dediščine ter njenega pomena in njeno učinkovitejše varstvo. Lokalni prebivalci bi imeli od tega tudi ekonomsko korist, pri svojem delovanju in splošnem razvoju pa bi se počutili manj prikrajšani in (za)varovanja ne bi več dojemali le kot razvojno oviro.

Do nedavna je udejanjanje interpretacije dediščine v narodnih parkih prepogosto temeljilo predvsem na urejanju poti, opremljenih s tablami in vodenju po poteh, kar je razvidno tudi iz analize udejanjanja interpretacije dediščine v TNP-ju in FNP-ju. V prihodnje je treba več poudarka nameniti celovitemu razvoju vseh sredstev interpretacije dediščine, saj z večjim naborom sredstev pritegnemo in dediščino približamo bolj raznolikemu občinstvu, poleg tega pa tudi same parke naredimo zanimivejše. Ob tem ne smemo pozabiti tudi na vse funkcionalno ovirane osebe in sredstva interpretacije prilagoditi njihovim potrebam ter zmožnostim.

Interpretacija dediščine pa bo v vseh narodnih parkih, tudi v TNP-ju in FNP-ju, zares učinkovita šele ko bodo upravljavci parkov pri njenem udejanjanju bolj sledili in upoštevali načela ter priporočila 
za uspešno interpretacijo dediščine. Predvsem bi morali pri vsaki interpretaciji dediščine določiti in jasno predstaviti temo, ki je najmočnejše orodje interpretacije (Ham 1992; Veverka 2011).

\section{Sklep}

Varstvo naravne in kulturne dediščine udejanjamo na različne načine, med katerimi je najbolj razširjeno njeno zavarovanje v obliki zavarovanih območij. Narodni parki in ostala zavarovana območja so v današnji obliki okoljevarstveni koncept, ki predstavlja vrh prizadevanj za varstvo dediščine ter temelj skoraj vseh narodnih in mednarodnih naravovarstvenih strategij.

Upravljavci narodnih parkov skušajo kljub prepletanju različnih želja in dejavnosti prednostno zagotoviti trajno varstvo naravne in kulturne dediščine tega območja. Da bi svojo temeljno vlogo lažje izpolnjevali, jo je družbi treba ustrezno predstaviti in poskrbeti, da bo le-ta doumela pomen in poslanstvo parkov. Šele tedaj se bodo upravljavci in vsi podporniki narodnih parkov lahko uspešneje spopadali z vsemi izzivi, ki jih srečujejo pri svojem delu.

Za ustvarjanje pomena, dojemanje in doumevanje poslanstva ter vloge narodnih parkov in dediščine so na voljo različna orodja, med katerimi se v zadnjih letih vse bolj uveljavlja interpretacija dediščine.

Interpretacija dediščine v narodnih parkih že dolgo ne koristi zgolj zabavanju in poučevanju obiskovalcev o lepotah parkov. Vse pogosteje se jo vključuje tudi v proces ustanavljanja in upravljanja parkov, predvsem upravljanja $\mathrm{z}$ obiskom, izvajanja trajnostnega turizma in večnamenskega povezovanja vseh deležnikov v parku.

Pregled udejanjanja interpretacije dediščine v TNP-ju in FNP-ju je pokazala, da obstaja še veliko neizkoriščenih priložnosti za izpopolnjenje in vsesplošno uveljavitev interpretacije dediščine na njunem območju. Na primeru tabel v parkih je namreč razvidno, da sredstva interpretacije obiskovalce prepogosto zgolj informirajo o dediščini in jim jo ne interpretirajo. Podobno je z interpretacijskimi vodenji, predstavljenimi vsebinami v središčih za obiskovalce in v tiskovinah. Poleg tega bo v obeh parkih treba več poudarka nameniti oblikovanju ustreznih načrtov interpretacije dediščine, vključevanju širšega kroga ljudi v udejanjanje interpretacije dediščine in skladnemu razvoju vseh sredstev interpretacije. Pri samem oblikovanju in rabi teh sredstev pa bo treba v večji meri upoštevati načela in priporočila za uspešno interpretacijo dediščine, kot so zagotoviti krožnost in ustrezno dolžino vseh poti, opremljenih s tablami, zagotoviti ustrezno število tabel ob teh poteh in stremeti h kakovostnemu ter preprostemu predstavljanju vsebin na samih tablah, zagotoviti zanimive naslovnice tiskovin ter $v$ interpretacijska vodenja po parkih vključiti več zanimivih zgodb iz življenja lokalnih prebivalcev in osebnih izkušenj obiskovalcev.

\section{Viri in literatura}

Baldauf, M., Ogorelec, B., Bogner, D., Brezavšček, L., Neuhold, U., Papež, A., Schitter, E., Šolar, M. 2011: Infrastruktura za doživljanje in spoznavanje narave, Smernice za inovativno načrtovanje. Bled.

Benton, G. M. 2009: From principle to practice, four conceptions of interpretation. Journal of Interpretation Research 14-1. Fort Collins.

Bizjak, J. 2004: Triglavski narodni park. Ljubljana.

Bizjak, J. 2011: Narodni park med vizijami, možnostmi in resničnostjo. Dvajset let pozneje: 1981-2001, 20 let Zakona o Triglavskem narodnem parku. Bled.

Convention Concerning the Protection of the World Cultural and Natural Heritage, 2015. Medmrežje: http://whc.unesco.org/en/conventiontext/ (16.5.2015)

Cvahte, A. 2013: Interpretacija naravne in kulturne dediščine v Triglavskem narodnem parku in Narodnem parku Fiordland (Nova Zelandija) v luči geografije. Diplomsko delo, Filozofska fakulteta Univerze v Ljubljani. Ljubljana. 
Department of Conservation. Statement of intent 2012-2017, 2012. Medmrežje: http://www.doc.govt.nz/ documents/about-doc/statement-of-intent-2012-2017/statement-of-intent-2012-2017.pdf (19.5.2015).

Department of Conservation. Annual Report for year ended 30 June 2014, 2014. Medmrežje: http://www.doc.govt.nz/about-us/our-role/corporate-publications/annual-reports-archive/ annual-report-for-year-ended-30-june-2014/ (19.5.2015).

DMV 25 - Digitalni model višin $25 \mathrm{~m} \times 25$ m. Geodetska uprava Republike Slovenije. Ljubljana, 2005.

DOC Public Conservation Areas, 2014. Medmrežje: https://koordinates.com/ (30.3.2015).

East Homer Nature Walk, 2015. Medmrežje: http://www.doc.govt.nz/parks-and-recreation/places-to-go/ fiordland/places/fiordland-national-park/things-to-do/tracks/east-homer-nature-walk/ (7.4.2015).

Erhartič, B., Smrekar, A., Šmid - Hribar, M., Tiran, J. 2012: Krajinski park Ljubljansko barje: interpretacija kulturne pokrajine. Geografski obzornik 59-3. Ljubljana.

FNP center za obiskovalce Te Anau. O poteh Fiordlandskega narodnega parka. Ustni vir. Te Anau, 2012.

GJI - zbirni kataster gospodarske javne infrastrukture. Geodetska uprava Republike Slovenije. Ljubljana, 2014.

Grošelj, A. 2008: Ocena metodologije ustanavljanja širših zavarovanih območij v Sloveniji. Magistrsko delo, Biotehniška fakulteta Univerze v Ljubljani. Ljubljana.

Groznik - Zeiler, K. 2011: Razvojna vloga zavarovanih območij v Sloveniji. Razvoj zavarovanih območij v Sloveniji, Regionalni razvoj 3. Ljubljana.

Ham, S. H. 1992: Environmental Interpretation. Colorado.

Ham, S.H. 2003: Ecotourism - Making a Difference by Making Meaning. Medmrežje: http://www.jonkohl.com/ publications/n-z/sham-keynote03.pdf (3.4.2015).

Harper, R. K. 1991: Interpretation in the national parks of New Zealand: The evolution and development of a management practice. Magistrsko delo, Univerza Lincoln. Christchurch.

Hlad, B. 2004: Interpretacija narave, Poročilo o seminarju in delavnici. Agencija Republike Slovenije za okolje. Ljubljana. Medmrežje: www.interpretacija.si/arhiv/porocilo_bistra.pdf (29.3.2015).

Hribar, M., Šmid - Hribar, M., Erhartič, B. 2011: Premislek o razvoju in zavarovanih območjih. Razvoj zavarovanih območij v Sloveniji, Regionalni razvoj 3. Ljubljana.

Improved NZ Road Centrelines (August 2011), 2011. Medmrežje: https://koordinates.com/ (30.3.2015).

Jarvis, A., Reuter, H. I., Nelson, A., Guevara, E. 2008: Hole-filled seamless SRTM data V4, International Centre for Tropical Agriculture (CIAT). Medmrežje: http://srtm.csi.cgiar.org (26.3.2015).

Kategorizacija vodotokov, 2003. Medmrežje: http://gis.arso.gov.si/ (2.4.2015).

Keršič - Svetel, M. 2002: Ekoturizem v gorah - Izkušnje v tujini, resničnost doma. Ekoturizem v gorah. Bled.

Keršič - Svetel, M. 2010: Strokovna izhodišča za smernice in standarde kakovosti na področju načrtovanja interpretacije dediščine podeželja. Identiteta je tudi interpretacija preteklosti. Cerknica.

Kus - Veenvielt, J., Sovinc, A. 2009: Učinkovitost upravljanja zavarovanih območij v Sloveniji. Medmrežje: http://www.mop.gov.si/fileadmin/mop.gov.si/pageuploads/podrocja/narava/rappam_porocilo.pdf (26.3.2015).

Lackey, B., K. 2008: The state of interpretation in academia. Journal of Interpretation Research 13-1. Fort Collins.

Lampič, B., Mrak, I. 2007: Nature conservation in Slovenia. Sustainable Environmental Research, Promoting International Cooperation and Mutual Assistance in Natural Parks. Olomouc.

Lampič, B., Mrak, I. 2008: Vrednote, vrednosti in razvojni potenciali območij varovanja. Dela 29. Ljubljana. DOI: http://dx.doi.org/10.4312/dela.29.11.145-159

Medmrežje 1: http://www.doc.govt.nz/ (30.3.2015).

Merriman, T., Brochu, L. 2004: Twelve trends in the interpretive profession. Journal of Interpretation Research 9-2. Fort Collins. 
Moscardo, G. 1996: Mindful visitors, heritage and tourism. Annals of Tourism Research 23-2. DOI: http://dx.doi.org/10.1016/0160-7383(95)00068-2

NZ Lake Polygons (Topo 1:50k), 2015. Medmrežje: https://koordinates.com/ (30.3.2015).

NZ Major Rivers, 2011. Medmrežje: https://koordinates.com/ (30.3.2015).

Ogorelec, B. 2004: Zakaj zavarovana območja potrebujejo interpretacijske poti? Medmrežje: http://www.gov.si/aplikacije/mop/interpretacija_narave/arhiv/pomen_ucnih_poti.pdf (9.4.2015).

Ogorelec, B. 2011: Načrtovanje in ustanavljanje novih naravnih parkov v Sloveniji, prvo desetletje začasne zaustavitve ustanavljanja regijskega parka Snežnik. Narava kot vrednota. Ljubljana.

Plut, D. 2008: Trajnostni razvoj varovanih območij - celostni pristop in aktivna vloga države, trajnostno gospodarjenje $\mathrm{v}$ varovanih območjih $\mathrm{z}$ vidika doseganja skladnejšega regionalnega razvoja. Elaborat, Filozofska fakulteta Univerze v Ljubljani. Ljubljana.

Pretner, M., Šolar, M. 2006: Mreža informacijskih mest v TNP - Strategija. Bled.

Ryan, C., Dewar, K. 1995: Evaluating the communication process betwen interpreter and visitor. Tourism Management 16-4. DOI: http://dx.doi.org/10.1016/0261-5177(95)00019-K

Scott, P. 2011: Populated Places - Points. Medmrežje: https://koordinates.com/ (30. 3. 2015).

Slovenska meja. Geodetska uprava Republike Slovenije. Ljubljana, 2008.

Smrekar, A., Šmid Hribar, M., Tiran, J., Erhartič, B. 2014: Interpretacija okolja na primeru Ljubljanskega barja. Georitem 24. Ljubljana.

Some staging posts in the history of interpretation. Interpret Europe. Medmrežje: http://www.interpreteurope.net/top/heritage-interpretation/history.html (2.4.2015).

Sovinc, A. 2011: Oblikovanje modela za učinkovito upravljanje zavarovanih območij narave. Doktorska disertacija, Fakulteta za humanistične študije Univerze v Kopru. Koper.

Sovinc, A., Fišer - Pečnikar, Ž., Gosar, A. 2011: Govorimo isti jezik? Primerjava mednarodnih in slovenskih meril kategorizacije zavarovanih območij. Razvoj zavarovanih območij v Sloveniji, Regionalni razvoj 3. Ljubljana.

Stoječe vode, 2003. Medmrežje: http://nfp-si.eionet.europa.eu/Dokumenti/GIS/splosno (Citirano 2.4.2015).

Šolar, M. 2009: Urejanje Triglavskega narodnega parka za obiskovalce v luči ciljev in namenov ustanovitve narodnega parka. Dela 31. Ljubljana. DOI: http://dx.doi.org/10.4312/dela.31.8.129-142

Šolar, M. 2012: Razvoj in udejanjanje interpretacije dediščine v Triglavskem narodnem parku. Ustni vir, 9. 1.2012. Ljubljana.

Thorsten, L. 2003: Basic Interpretive Skills, The Course Manual. Werleshausen. Medmrežje: http://www.videsgidi.lv/faili/Basic_Interpretive_Skills_-_The_Course_Manual.pdf (3.4.2015).

Vadala, C. E., Bixler, R. D., Hammitt, W.E. 2006: A public's awareness of regional parks and park management agencies with implications for management-oriented interpretation. Journal of Interpretation Research 11-2. Fort Collins.

Veverka, J. 2011: Interpretive Master Planning. Edinburg.

Veverka, J. 2015: John Veverka \& Associates. Medmrežje: http://www.heritageinterp.com/ (31.3. 2015).

Wallace, G. N., Pierce, S. M. 1996: An evolution of ecotourism in Amazonas, Brazil. Annals of Tourism Research 23. DOI: http://dx.doi.org/10.1016/0160-7383(96)00009-6

Wearing, S., Edinborough, P., Hodgson, L., Frew, E. 2008: Enhancing Visitor Experience Through Interpretation. Medmrežje: http://www.crctourism.com.au/wms/upload/resources/80035_Wearing_ EnhancingVisExp_WEB.pdf (3.4.2015).

Winter, P., L. 2006: The impact of normative message types on off-trail hiking. Journal of Interpretation Research 11-1. Fort Collins.

Zavarovana območja (poligoni), 2013. Medmrežje: http://gis.arso.gov.si/ (2.4.2015). 


\section{Summary: The role of heritage interpretation in national parks}

(translated by Živa Malovrh)

The main purpose of the paper is to assess the role of heritage interpretation in solving the key challenges facing national parks (e.g. effective management of national parks, increasing their popularity, implementing a sustainably devised tourism, and raising the public's awareness on the importance of parks natural and cultural heritage) and analysis of the implementation of heritage interpretation in the Triglav National Park in Slovenia and the Fiordland National Park in New Zealand.

Natural and cultural heritage conservation can be realized by implementing various measures. Protection in the form of national parks is one of the most popular ways to achieve this. The fundamental role of national parks is to ensure a permanent protection of the natural values, the cultural heritage, the landscape diversity, and the biodiversity. However, even though society views national parks and conserving the natural and cultural heritage within them favourably in principle, the reality is often expressed in a stepmotherly attitude. The managers and other supporters of national parks therefore often encounter different challenges and problems in their work that mostly stem from the fact that the meaning and role of national parks have not been precisely defined. This unclear definition of parks along with the varying and often excluding plans and wishes within the parks causes increasing tension between the managers and the other stakeholders.

In order for national parks to fulfil their fundamental role better and receive wider support, the government apparatus, along with the public and the local inhabitants must take an interest in the matter. They must identify with the natural and cultural heritage in their area, be proud of it, understand and respect it. It is vital for them to grasp and understand the national parks' mission and to develop a sense of responsibility and a need for being included in the conservation of their own natural and cultural heritage. This can be achieved in different ways; the most recently gaining in attention is heritage interpretation. Using this method, the national parks have the opportunity to present their "story" and role to the general public and to reveal the meaning of what they are interpreting. Heritage interpretation has also started to be included in the processes of founding and managing national parks, especially in visitor management.

Heritage interpretation in the widest sense has been present for a long time, but in the modern sense it is a more recent phenomenon that is closely connected to the evolution of national parks and establishing tourist activities in them. The origins of heritage interpretation stem from the time the first national parks were being founded and developed in the United States of America; nowadays, the concept is being diligently observed in national parks all around the world. The general consensus is that it is most established in the national parks of English-speaking countries, where it has the longest-running tradition.

Through the decades, different self-guided and personal media of heritage interpretation have been created. Among the self-guided media, the most established in national parks are signboards, self-guided trails, interpretation centres, printed materials, exhibitions, websites, and interactive presentations, while the most popular personal media consists of guided tours, storytelling, depicting, performing, teaching, workshops and courses. These media can be used to reach educational (what to learn), behavioural (how to behave, where to walk in the park and which areas may be visited), and emotional (what to feel towards the area) goals as well as to entertain the park visitors.

A comparison of how heritage interpretation is implemented in the Triglav National Park and the Fiordland National Park, with an emphasis on the self-guided trails, has indicated that despite a shorter-standing tradition, the heritage interpretation is no less adequate in quality in the former than in the latter park. Heritage interpretation is being diligently carried out in both parks, even though the development, contents, means, manner, and reasons for its implementation differ somewhat between them. Even though the heritage interpretation already reaches quite a high standard in many regards, an abundance of unused opportunities remain in both parks, waiting to be utilized. The key task for 
both parks is to focus more attention on the interpreting and not so much on merely informing the visitors on the heritage.

The Triglav National Park, the Fiordland National Park, as well as numerous other national parks around the world will have to place more emphasis on forming the appropriate plans for heritage interpretation that will adhere to the principles of heritage interpretation and the recommendations for a successful heritage interpretation, a proportionate development of the self-guided and personal interpretation media, and on involving a wider sphere of people into its implementation in the national parks. 
